\title{
Expression of CCR2A, an isoform of MCP-1 receptor, is increased by MCP-1, CD40 ligand and TGF- $\beta$ in fibroblast like synoviocytes of patients with RA
}

\author{
Mi-La Cho ${ }^{1 *}$, Bo-Young Yoon ${ }^{2 *}$, \\ Ji-Hyeon $\mathrm{Ju}^{1}$, Young Ok Jung ${ }^{3}$, \\ Joo-Yeon Jhun ${ }^{1}$, Mi-Kyung Park', \\ Sung-Hwan Park ${ }^{1}$, Chul-Soo Cho ${ }^{1}$ \\ and Ho-Youn Kim ${ }^{1,4}$ \\ ${ }^{1}$ Department of Internal Medicine, Division of Rheumatology \\ The Center for Rheumatic Diseases \\ The Rheumatism Research Center \\ Catholic Research Institutes of Medical Sciences \\ The Catholic University of Korea \\ Seoul 137-701, Korea \\ 2Department of Internal Medicine \\ Inje University Ilsan Paik Hospital \\ Goyang 411-706, Korea \\ ${ }^{3}$ Department of Internal Medicine, Division of Rheumatology \\ Hallym University Kang-Nam Sacred Heart Hospital \\ Seoul 150-950, Korea \\ ${ }^{4}$ Corresponding author: Tel, 82-2-590-2533; \\ Fax, 82-2-537-4673; E-mail, iammila@ cmc.cuk.ac.kr \\ ${ }^{*}$ These authors contributed equally to this work.
}

Accepted 4 June 2007

Abbreviations: FLS, fibroblast-like synoviocytes; MCP-1, monocyte chemoattractant protein 1; RA, rheumatoid arthritis

\begin{abstract}
Cytokine and chemokine receptors play a key role in inflammation caused by rheumatoid arthritis (RA). Two isoforms of human CC chemokine receptor R2 (CCR2), the receptor of monocyte chemoattractant protein 1 (MCP-1), have been identified but their relative expression in fibroblast-like synoviocytes (FLS) and their contribution to inflammatory responses mediated by MCP-1 or inflammatory cytokines in patients with RA remain uncertain. We examined the pattern of expression of two CCR2 isoforms upon stimulation by proinflammatory cytokines and CD40 ligation. FLS were prepared from the synovial tissues of RA patients and cultured in the presence of MCP-1, soluble CD40 ligand (sCD40L), TGF- $\beta$, IL-1 $\beta$, IL-18, IL-15, and LPS. CCR2A and CCR2B expression was examined by immunohistochemistry, RT-PCR and western blot
\end{abstract}

analysis. IL-15, TNF- $\alpha$, and MCP-1 production was determined by ELISA. Immunohistochemistry showed that CCR2A is highly expressed in RA synovium compared with OA synovium. Transcripts of both CCR2A and CCR2B were detected in FLS. Exogenous MCP-1, CD40L, TGF- $\beta$, and IL-15 significantly increased the expression of CCR2A but not CCR2B. Exposure of FLS to $S C D 40 \mathrm{~L}$ caused strong upregulation of CCR2A but not of CCR2B protein expression. MCP-1 increased the proliferation of FLS and the production of IL-15, TNF- $\alpha$, and IL-18. Because CCR2A is the main target of regulation by cytokines and CD40 ligation, the relatively higher expression of CCR2A on the cell surface suggests that this isoform of MCP-1 receptor functions as the principal mediator of inflammatory signals in RA FLS.

Keywords: arthritis, rheumatoid; CCR2 receptor; CD40 ligand; chemokine CCL2; cytokines; synovial membrane

\section{Introduction}

Rheumatoid arthritis (RA) is a chronic inflammatory disease characterized by hyperplasia of synovial cells, mononuclear cell infiltration, and angiogenesis, which ultimately lead to the destruction of cartilage and bone (Springer, 1994; Koch, 1998; Weyand, 2000). Various cytokines and chemokines have been implicated in the development of RA. Several studies have examined the pathogenic role of chemokine and chemokine receptor interactions in RA.

Cytokines and chemokine receptors regulate the migration of inflammatory cells and are regarded as possible therapeutic targets in inflammatory diseases. In RA, the major chemokine receptors related to migration of inflammatory cells are CC chemokine receptor 1 (CCR1), CCR2, CCR5, chemokine (C-X-C) receptor (CXCR3), and CXCR4, which react to different sites, such as peripheral blood, synovial fluid, and synovial tissue monocytes (Mack et al.,1999; Katschke et al., 2001; Nanki et al., 2001; Ruth et al., 2001; García-Vicuña et al., 2004). Among these chemokine receptors, CCR2 is expressed abundantly and plays a key 
role in RA (Katschke et al., 2001; Ruth et al., 2001; García-Vicuña et al., 2004).

CCR2 is a seven-transmembrane G-proteincoupled receptor that interacts with several ligands, the best understood of which are monocyte chemoattractant protein 1 (MCP-1) and CCL2. MCP-1 and CCR2 also play a role in human crescentic glomerulonephritis, pulmonary fibrosis, and other inflammatory arthritis models such as collagen-induced arthritis and adjuvant-induced arthritis (Segerer et al., 2000; Moore et al., 2001; Shahrara et al., 2003; Brühl et al., 2004; Quinones et al., 2005).

Chemokines also play a major role in transplantation rejection. Prolonged cardiac allograft survival has been achieved in CCR2 knockout mice and the risk of acute rejection in renal transplantation is associated with CCR2 and CCR5 polymorphism (Hancock et al., 2000; Abdi et al., 2002).

Both CCR2 and CCL2 knockout mice are protected from experimental autoimmune encephalomyelitis (EAE) (Fife et al., 2000; Huang et al., 2001). A recent report described the characterization of INCB3344, a novel, potent and selective small molecule antagonist of the mouse CCR2 receptor (Brodmerkel et al., 2005). In vivo, INCB3344 inhibits macrophage influx and is efficacious in the mouse EAE and in the rat adjuvant arthritis model.

MCP-1 expression is elevated in the inflamed synovium of RA and its expression is reduced by antiarthritic drugs (Koch et al., 1992; Loetscher et al., 1994). MCP-1 synthesis has been detected in endothelial cells, epithelial cells, fibroblasts, monocyte-macrophages, vascular smooth muscle cells, and almost all other cells (Wang et al., 1991; Paine et al., 1993).

CCR2 has two alternatively spliced forms-CCR2A and CCR2B-which differ only in their carboxylterminal tails (Charo et al., 1994). CCR2A and CCR2B are upregulated and expressed by different cell subsets in idiopathic inflammatory myopathies (IIM) (Bartoli et al., 2001). CCR2A is the major isoform expressed by mononuclear cells and is strongly upregulated in IIM and vascular smooth muscle cells. CCR2B is expressed by satellite and regenerative muscle fibers. These results identify CCR2A as a possible new target for therapy in IIM. Other investigators observed that monocyte and activated NK cells express predominantly CCR2B and have low levels of CCR2A transcripts (Polentarutti et al., 1997). One study found functional differences between CCR2A and CCR2B in a Jurkat $T$ cell line (Sanders et al., 2000).

We examined the expression of two isoforms of
CCR2 and their stimulation by proinflammatory cytokines and CD40 ligation in FLS from patients with RA.

\section{Materials and Methods}

\section{Patients}

Seven RA patients fulfilling the 1987 revised criteria of the American College of Rheumatology (formerly, the American Rheumatism Association) took part in this study. The seven RA patients were compared with three age- and sex-matched control patients with osteoarthritis (OA). All patients were undergoing knee replacement surgery.

\section{Reagents}

Recombinant MCP-1, soluble CD40 ligand (sCD40L), IL-18, and IL-15 were purchased from R\&D Systems (Minneapolis, MN). Recombinant TGF- $\beta$ was purchased from Peprotech (London, UK). Recombinant TNF- $\alpha$ and IL-1 $\beta$ were purchased from Endogen Inc. (Cambridge, MA). LPS was obtained from Sigma Chemical Co. (St. Louis, MO). Antibodies to CCR2A and CCR2B used for immunohistochemistry were obtained from Santa Cruz Biotechnology Inc. (Santa Cruz, CA).

\section{Isolation of synovial fibroblasts}

Synoviocytes were isolated by the enzymatic digestion of synovial tissues obtained from patients with RA undergoing total joint replacement surgery. The tissues were minced into 2-3 $\mathrm{mm}$ pieces and treated for $4 \mathrm{~h}$ with $4 \mathrm{mg} / \mathrm{ml}$ of type I collagenase (Worthington Biochemical, Freehold, NJ) in DMEM at $37^{\circ} \mathrm{C}$ in $5 \% \mathrm{CO}_{2}$. Dissociated cells were centrifuged at $500 \mathrm{~g}$; resuspended in DMEM supplemented with 10\% FCS, 2 mM l-glutamine, 100 $\mathrm{U} / \mathrm{ml}$ penicillin, and $100 \mu \mathrm{g} / \mathrm{ml}$ streptomycin; and plated in $75 \mathrm{~cm}^{2}$ flasks. After overnight culture, nonadherent cells were removed and adherent cells were cultivated in DMEM supplemented with $20 \%$ FCS. The cultures were kept at $37^{\circ} \mathrm{C}$ in $5 \%$ $\mathrm{CO}_{2}$, and the medium was replaced every $3 \mathrm{~d}$. When the cells approached confluence, they were diluted 1:3 with fresh medium and passaged. Synoviocytes from passages 4-8 were used in each experiment. The cells were morphologically homogeneous and exhibited the appearance of synovial fibroblasts with typical bipolar configuration under inverse microscopy. The purity of the cells $\left(1 \times 10^{4}\right)$ was tested by flow cytometric analysis using phycoerythrin (PE)-conjugated antiCD14 (PharMingen, San Diego, CA) and FITC- 
conjugated anti-CD3 or anti-Thy-1 (CD90) monoclonal antibodies (PharMingen). At passage 4, most cells ( $>95 \%$ ) expressed the surface markers for fibroblasts (Thy-1), whereas $3.5 \%$ of cells were CD14+ and $<1 \%$ of cells were CD $3+$.

\section{Immunohistochemistry of synovial tissues}

Tissue samples were fixed immediately with $4 \%$ formaldehyde and embedded in paraffin. For CCR2A and CCR2B staining, samples were deparaffinized and dehydrated, and the sections were blocked with normal serum followed by $60 \mathrm{~min}$ of incubation with antibodies against CCR2A and CCR2B at concentrations of $5 \mu \mathrm{g} / \mathrm{ml}$ each. Endogenous peroxidase was blocked with $3 \% \mathrm{H}_{2} \mathrm{O}_{2}$ in methanol for $15 \mathrm{~min}$, and the samples were incubated with secondary antibody, biotinylated swine anti-rabbit lgG, for $30 \mathrm{~min}$. Slides were stained with streptavidin-peroxidase, developed with 3-3'-diaminobenzidine, and counterstained with hematoxylin for $30 \mathrm{~s}$. Staining of CCR2A and CCR2B at $400 \times$ magnification was scored semiquantitatively on a five-point scale.

\section{Methyl-tetrazolium assay}

Sixty thousand cells were subcultured in each well of a 24-well plate for 1-7 $d$ and washed with DMEM without FBS. MCP-1 $(1-50 \mathrm{ng} / \mathrm{ml})$ was added to each well, and the MTT assay was used to assess cell viability (Nawrot et al., 2000). $4 \mathrm{~h}$ after exposure to light, MTT was added to each well (20 $\mu \mathrm{l}$ MTT in $2.5 \mathrm{mg} / \mathrm{ml} \mathrm{PBS}$ ), and the cells were incubated for $4 \mathrm{~h}$ at $37^{\circ} \mathrm{C}$. The culture medium containing MTT was removed, and $100 \mu \mathrm{L}$ DMSO was added to each well to solubilize the blue formazan formed by the viable cells. The plates were read by an ELISA plate reader (Vmax, Molecular Devices, Palo Alto, CA) at wavelengths of 570 and $690 \mathrm{~nm}$. Cell viability was expressed as a percentage of exposed cells relative to control cells.

\section{Expression of CCR2A and CCR2B mRNA determined by RT-PCR}

Synovial fibroblasts were incubated with MCP-1 $(50 \mathrm{ng} / \mathrm{ml}), \mathrm{sCD} 40 \mathrm{~L}(10 \mathrm{ng} / \mathrm{ml})$, TGF- $\beta \quad(10 \mathrm{ng} / \mathrm{ml})$, IL-1 $\beta$ (10 $\mathrm{ng} / \mathrm{ml}), \quad I L-18 \quad(10 \mathrm{ng} / \mathrm{ml}), \quad I L-15$ (10 $\mathrm{ng} / \mathrm{ml})$, LPS $(10 \mu \mathrm{g} / \mathrm{ml})$, or SCD40L $(1-50 \mathrm{ng} / \mathrm{ml})$. After $12 \mathrm{~h}$ of incubation, mRNA was extracted using RNAzol B (Biotex Laboratories, Houston, TX) according to the manufacturer's instructions. Reverse transcription of $2 \mu \mathrm{g}$ total mRNA was carried out at $42^{\circ} \mathrm{C}$ using the Superscript ${ }^{\mathrm{TM}}$ reverse trans- cription system (Takara, Shiga, Japan). PCR amplification of cDNA aliquots was performed by adding $2.5 \mathrm{mM}$ dNTPs, $2.5 \mathrm{U}$ Taq DNA polymerase (Takara), and $0.25 \mu \mathrm{M}$ of sense and antisense primers. The reaction was performed in $25 \mu \mathrm{l}$ of PCR buffer $(1.5 \mathrm{mM} \mathrm{MgCl} 2,50 \mathrm{mM} \mathrm{KCl}, 10 \mathrm{mM}$ Tris- $\mathrm{HCl}, \mathrm{pH}$ 8.3). The following sense and antisense primers for each molecule were used: for human CCR2, 5'-ATTCACAGGGCTGTATCAC-3' (sense) and 5'-GTGGAAAATAAGGGCCACAGAC3' (antisense); for human CCR2A, 5'-CATTAGCCTATGTGCATGC-3' (sense) and 5'-TTACTTCAGGGGAGCTTCTCC-3' (antisense); for human CCR2B, 5'-TGGACAAAGACAAAGGTG-3' (sense) and 5'-AAGAAGCATCTGAACAATGG-3' (antisense); and for human GAPDH, 5'-CGATGCTGGGCGTGAGTAC-3' (sense) and 5'-CGTTCAGCTCAGGGATGACC-3' (antisense). Reactions were processed in a DNA thermal cycler (PerkinElmer Cetus, Wellesley, MA) through 35 cycles at $94^{\circ} \mathrm{C}$ for $30 \mathrm{~s}$, $57^{\circ} \mathrm{C}$ for $30 \mathrm{~s}$, and $72^{\circ} \mathrm{C}$ for $30 \mathrm{~s}$ for CCR2, CCR2A and CCR2B; and 25 cycles of $94^{\circ} \mathrm{C}$ for $30 \mathrm{~s}, 56^{\circ} \mathrm{C}$ for $30 \mathrm{~s}$, and $72^{\circ} \mathrm{C}$ for $30 \mathrm{~s}$ for GAPDH. PCR products were run on a $1.5 \%$ agarose gel and stained with ethidium bromide. Results are expressed as the ratio of CCR2, CCR2A, or CCR2B PCR product to GAPDH product.

\section{Concentrations of IL-15, TNF- $\alpha$, and IL-18 determined by sandwich ELISA}

FLS were pretreated for $30 \mathrm{~min}$ in the presence and absence of CCR2A- or CCR2B-blocking antibody $(20 \mu \mathrm{g} / \mathrm{ml})$ before exposure to MCP-1 (1-50 $\mathrm{ng} / \mathrm{ml}$ ) for $48 \mathrm{~h}$. IL-15, TNF- $\alpha$, and IL-18 secretion was assessed at $48 \mathrm{~h}$ by sandwich ELISA analysis as described. FLS were added to a 96-well plate (NUNC, Denmark) with $4 \mu \mathrm{g} / \mathrm{ml}$ of antibodies to human IL-15, TNF- $\alpha$, or IL-18 (R\&D Systems) and incubated overnight at $4{ }^{\circ} \mathrm{C}$. The wells were blocked with PBS containing 1\% BSA and $0.05 \%$ Tween 20 for $2 \mathrm{~h}$ at room temperature. The test samples and standards of recombinant human IL-15, TNF- $\alpha$, or IL-18 (R\&D Systems) were added to the plate and incubated at room temperature for $2 \mathrm{~h}$. Plates were washed four times with PBSTween $20,400 \mathrm{ng} / \mathrm{ml}$ of biotinylated polyclonal antibodies to human IL-15, TNF- $\alpha$, or IL-18 (R\&D Systems) were added, and the reaction was allowed to proceed for $2 \mathrm{~h}$ at room temperature. The plate was washed, streptavidin-alkaline phosphatase (Sigma; diluted 1:2,000) was added, and the reaction was allowed to proceed for $2 \mathrm{~h}$. The plate was washed four times, $50 \mu$ of diluted avidin-peroxidase (1:2,000 in diluent) was added, and the plate was incubated for $2 \mathrm{~h}$ at room 
temperature. Fifty microliters of TMB substrate solution (Kirkegaard \& Perry Laboratories, Guildford, UK) was added to each well and the plate was incubated for 20-30 $\mathrm{min}$. The initial reaction produced a blue color that was monitored by absorbance at $595 \mathrm{~nm}$ with a microplate reader (MRX Revelation, Dynex Technologies, Chantilly, VA). When the desired intensity was reached (OD $<0.8)$, sulfuric acid $(2.0 \mathrm{~mol} / \mathrm{l})$ was added to each well $(50 \mu \mathrm{l})$ to stop the color-generating reaction. An automated microplate reader (Vmax, Molecular Devices, Palo Alto, CA) set at $450 \mathrm{~nm}$ was used to measure the OD. The sensitivity limit was 15.6 $\mathrm{pg} / \mathrm{ml}$ for human IL-15, TNF- $\alpha$, and IL-18. Recombinant human cytokines diluted in culture medium were used as a calibration standard over the concentration range of $10-2,000 \mathrm{pg} / \mathrm{ml}$. A standard curve was drawn by plotting OD versus the log of the concentration of recombinant cytokine.

\section{Western blot analysis}

FLS were incubated with sCD40L $(10 \mathrm{ng} / \mathrm{ml})$, TGF- $\beta$ (10 $\mathrm{ng} / \mathrm{ml})$, and MCP-1 $(50 \mathrm{ng} / \mathrm{ml})$. Cell lysates were analyzed for CCR2A and CCR2B activation by western blot analysis. Whole cell lysates were prepared from about $5 \times 10^{6}$ cells by homogenization in lysis buffer and centrifuged at $19,000 \mathrm{~g}$ for $15 \mathrm{~min}$. Protein concentrations in the supernatants were determined with the Bradford method (Bio-Rad, Hercules, CA). Protein samples were separated by SDS-PAGE and transferred to a nitrocellulose membrane (Amersham Pharmacia Biotech, Uppsala, Sweden). For western hybridization, the membrane was preincubated with $5 \%$ skim milk in Tris-buffered saline (TBS) for $2 \mathrm{~h}$ at room temperature. Primary antibodies against CCR2A and CCR2B, diluted $1: 1,000$ in 5\% BSATBS-T $(0.1 \%$ Tween 20 in TBS) were added and the samples were incubated overnight at $4^{\circ} \mathrm{C}$. The samples were washed four times with TBS-T, HRP-conjugated secondary antibodies were added, and the samples were incubated for $1 \mathrm{~h}$ at room temperature. The samples were washed in TBS-T, and the hybridized bands were detected with an enhanced chemiluminescence (ECL) detection kit (Pierce, Rockford, IL) and Hyperfilm-ECL reagents (Agfa, Belgium).

\section{Statistical analysis}

Data are expressed as means \pm SD. The results were analyzed using a nonparametric MannWhitney $U$ test or paired Wilcoxon's signed-rank test. $P<0.05$ was considered significant.

\section{Results}

\section{Increased expression of CCR2A in patients with RA}

To localize CCR2A and CCR2B expression in joint tissue sections of patients with RA or OA, the samples were stained with anti-CCR2A or CCR2B monoclonal antibodies or with irrelevant primary isotype-specific antibodies as a negative control. Immunohistochemical stains of RA synovium revealed pronounced expression of CCR2A in the synovial lining and the sublining of the RA synovium compared with $\mathrm{OA}$ synovium, and at sites of lymphocyte infiltration. In contrast, little CCR2B staining was observed in the synovium
CCR2A
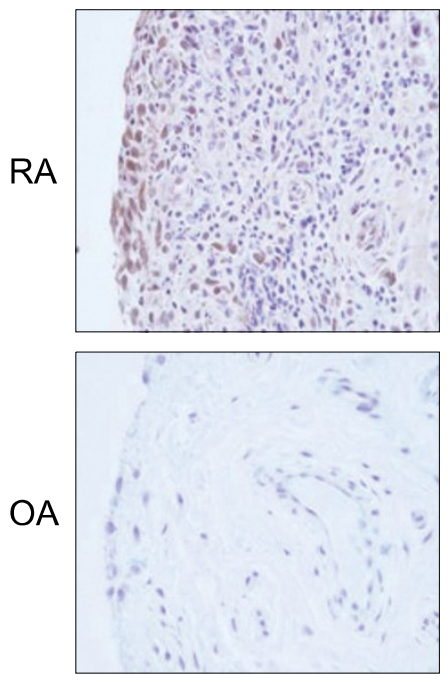

CCR2B
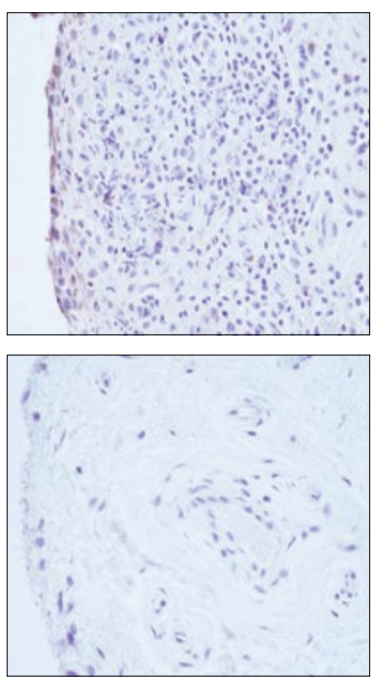

$H \& E$
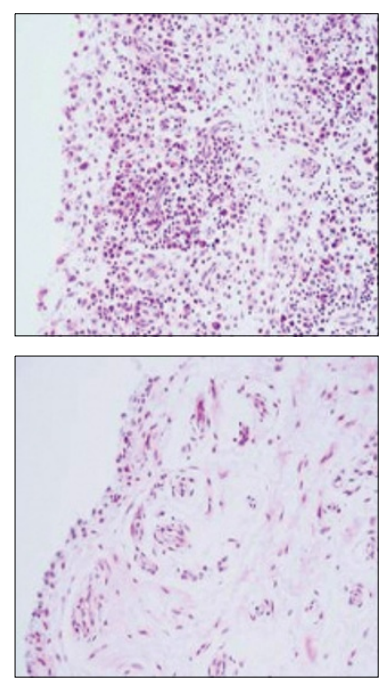

Figure 1. The expression of CCR2A and CCR2B in the synovial membrane from RA patients. The expression of CCR2A and CCR2B in the synovium of $\mathrm{RA}$ and $\mathrm{OA}$. Immunostaining was performed using specific antibodies. Isotype- and concentration-matched negative control specimen from the same RA patient or $\mathrm{OA}$ patient. (Original magnification $400 \times$ ). 
(Figure 1). These data show that expression of CCR2A is significantly higher than that of CCR2B in the lining of moderately inflamed synovium.

\section{MCP-1 induces different expression of CCR2A and CCR2B mRNA in RA FLS}

We used RT-PCR to measure the mRNA expre- ssion of CCR2A, CCR2B, and total CCR2 in response to different concentrations of MCP-1 (10 and $50 \mathrm{ng} / \mathrm{ml}$ ) in RA FLS (Figure 2). Exogenous MCP-1 increased the signal for total CCR2 and CCR2A expression in a dose-dependent manner in RA-FLS compared with OA-FLS, but had no effect on the signal for CCR2B PCR product.
A
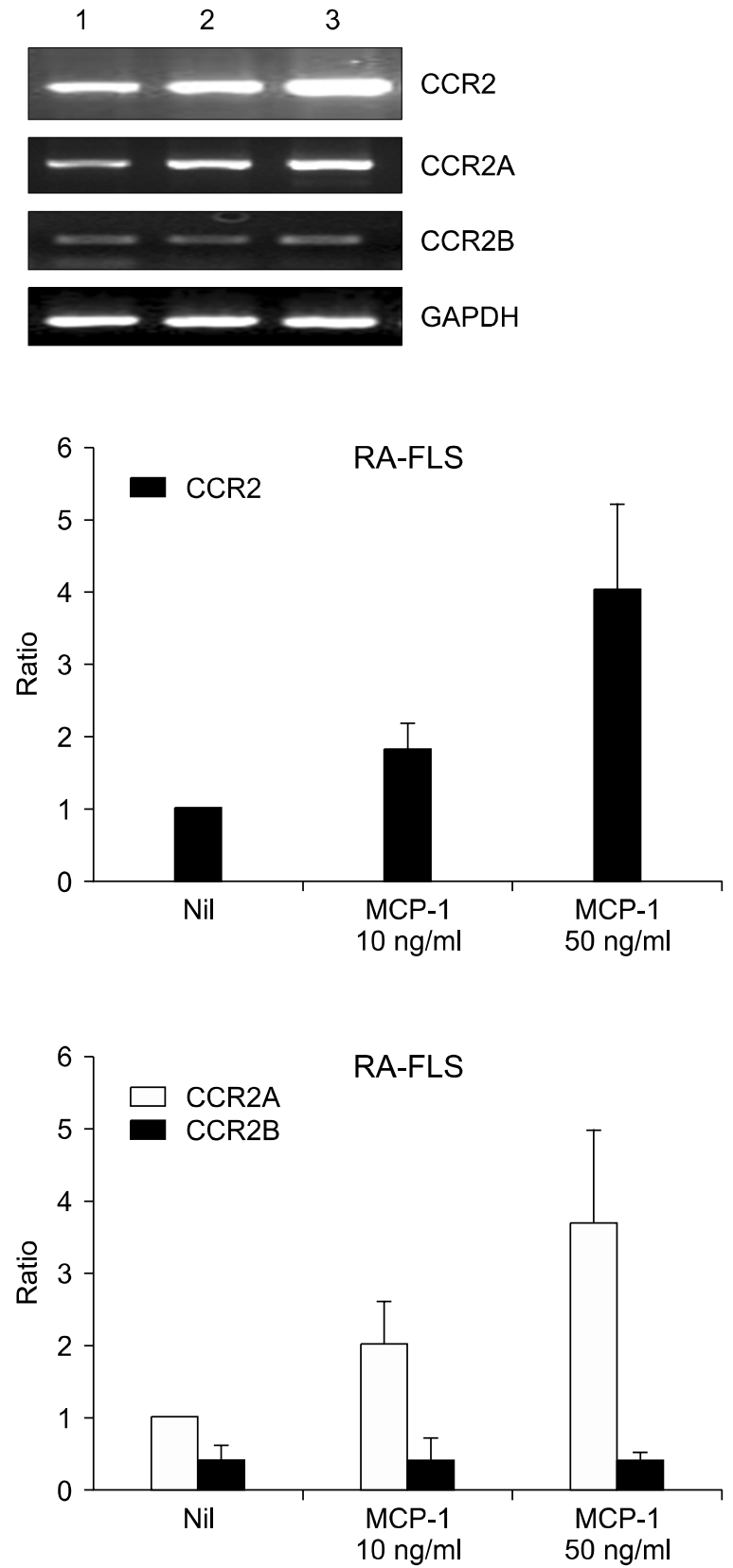

B
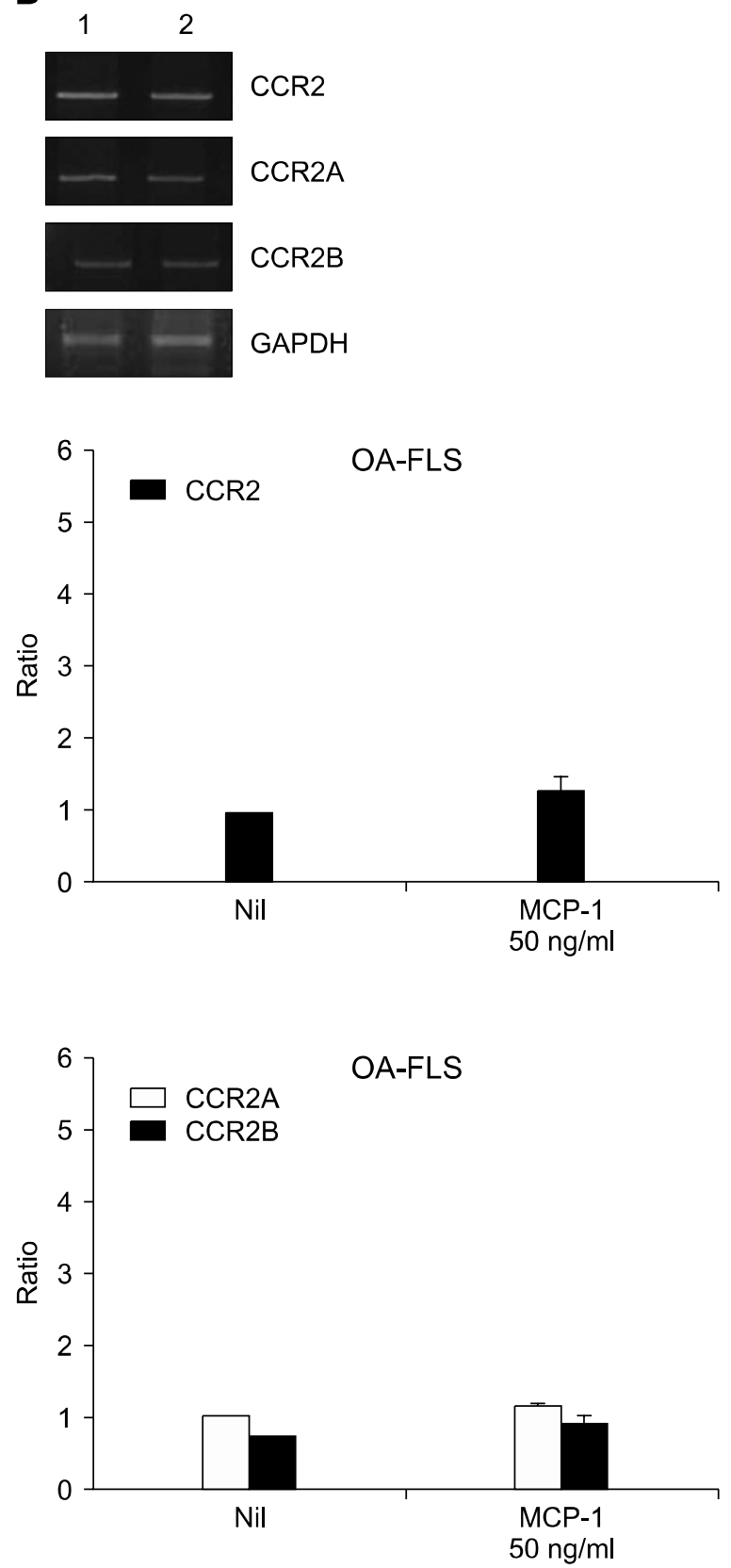

Figure 2. Effect of MCP-1 stimulation on the expression of CCR2A and CCR2B in the FLS from RA patients. (A) RA-FLS were cultured with the indicated concentration of MCP-1 for $12 \mathrm{~h}$. The expression of CCR2, CCR2A, and CCR2B mRNAs was evaluated by RT-PCR. The OD of each band was normalized to that of GAPDH. The data are representative of three similar experiments. (B) OA-FLS were also cultured with MCP-1 for $12 \mathrm{~h}$. 
A $\begin{array}{llllllll}1 & 2 & 3 & 4 & 5 & 6 & 7 & 8\end{array}$
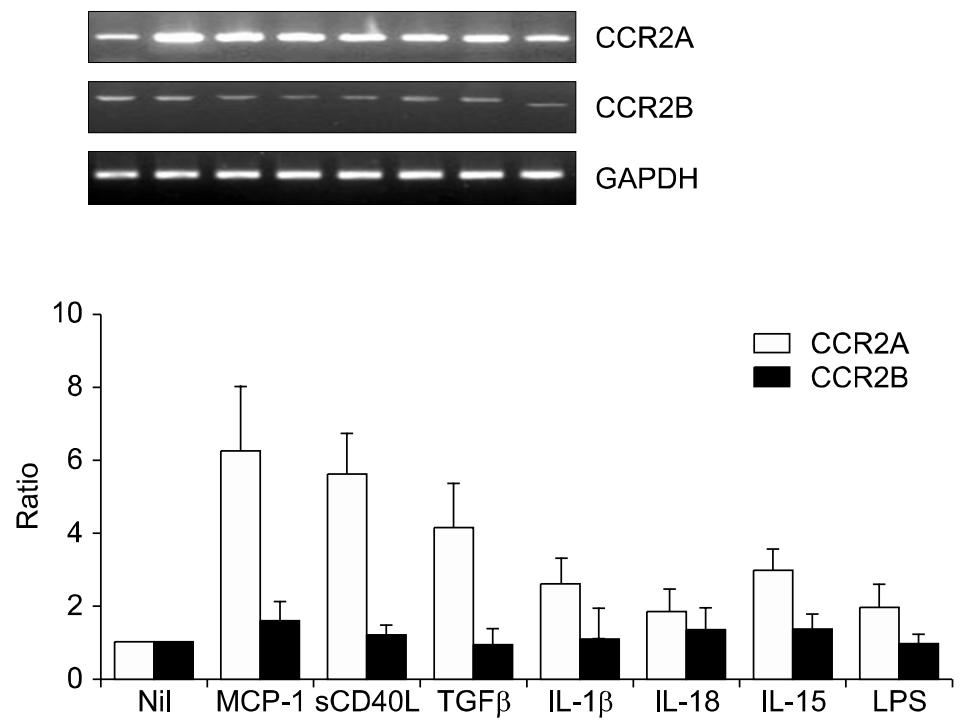

B
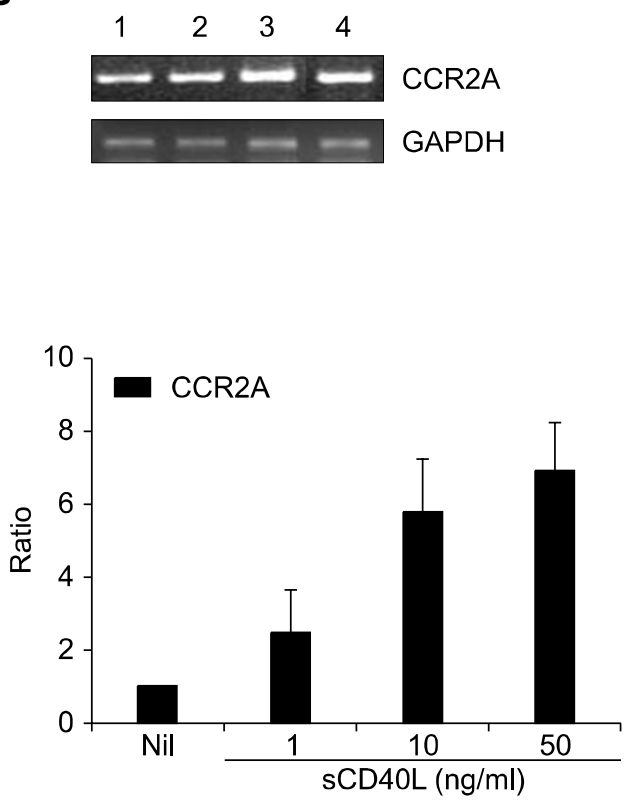

Figure 3. Cytokines and $\mathrm{SCD} 40 \mathrm{~L}$ induce differential $\mathrm{mRNA}$ expression of CCR2A and CCR2B in RA FLS. (A) FLS were incubated with MCP-1 (50 $\mathrm{ng} / \mathrm{ml})$, SCD40L (10 ng/ml), TGF- $\beta$ (10 ng/ml), IL-1 $1(10 \mathrm{ng} / \mathrm{ml}), \mathrm{LL}-18(10 \mathrm{ng} / \mathrm{ml}), \mathrm{LL}-15(10 \mathrm{ng} / \mathrm{ml})$, LPS $(10 \mu \mathrm{g} / \mathrm{ml})$, or (B) sCD40L (1-50 ng/ml). CCR2A and CCR2B mRNA levels were measured using semiquantitative RT-PCR. GAPDH mRNA was used as the internal control for even loading. The data are representative of three similar experiments.

\section{Cytokines and SCD40L induce different expression of CCR2A and CCR2B in RA FLS}

FLS were incubated with MCP-1 $(50 \mathrm{ng} / \mathrm{ml})$, sCD40L (10 ng/ml), TGF- $\beta$ (10 ng/ml), IL-1 $\beta$ (10 $\mathrm{ng} / \mathrm{ml}), \mathrm{IL}-18(10 \mathrm{ng} / \mathrm{ml}), \mathrm{IL}-15(10 \mathrm{ng} / \mathrm{ml})$, LPS (10 $\mu \mathrm{g} / \mathrm{ml})$, or SCD40L $(1-50 \mathrm{ng} / \mathrm{ml})$. CCR2A and CCR2B mRNA levels were measured using semiquantitative RT-PCR, with GAPDH mRNA as an internal control for even loading. As shown in Figure 3A, 3B, CCR2A was induced by various cytokines and CD40L, whereas CCR2B was induced only weakly by the same cytokines and CD40L. FLS were incubated with SCD40L (10 $\mathrm{ng} / \mathrm{ml})$, TGF- $\beta(10 \mathrm{ng} / \mathrm{ml})$, and MCP-1 $(50 \mathrm{ng} / \mathrm{ml})$. CCR2A and CCR2B protein levels were analyzed using western blotting, with $\beta$-actin as an internal control for even loading. SCD40L, TGF- $\beta$, and MCP-1 induced CCR2A protein but not CCR2B protein (Figure 4).

\section{Induction of FLS cellular proliferation and cytokine production by MCP-1}

To determine whether MCP-1 induces cell proliferation and cytokine production by FLS, MCP-1 was added to FLS cultured for 1-7 d. MCP-1 induced FLS proliferation in a dose-dependent (1-50 $\mathrm{ng} / \mathrm{ml})$ and time-dependent (1, 3, 5, 7 d) manner (Figure 5). MCP-1 induced the production of pro-
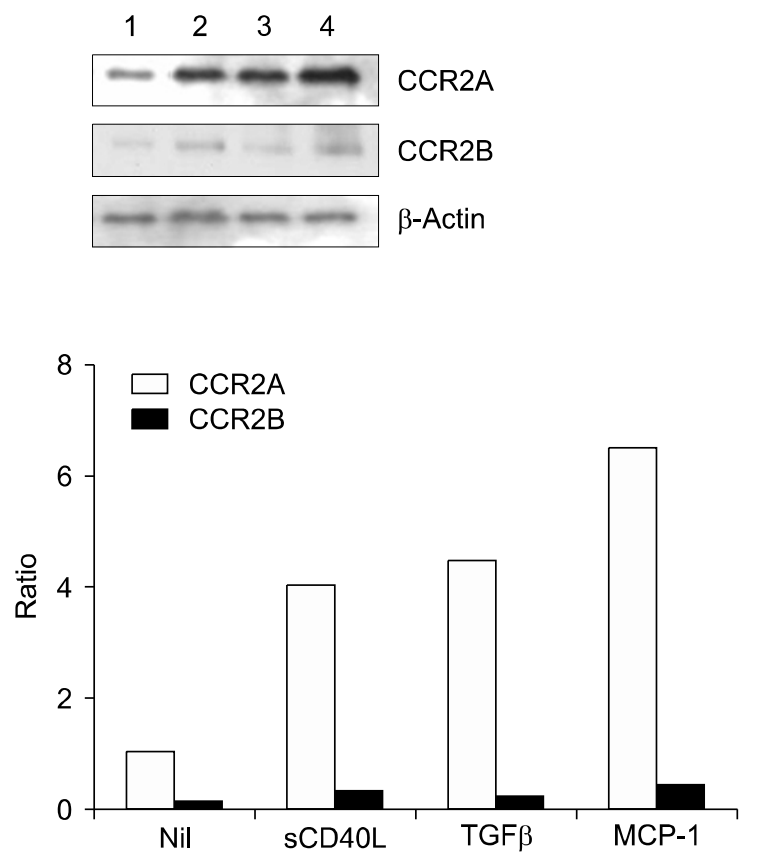

Figure 4. SCD40L, TGF- $\beta$, and MCP-1 induce differential protein expression of CCR2A and CCR2B in RA FLS. FLS were incubated with SCD40L (10 ng/ml), TGF- $\beta$ (10 ng/ml), and MCP-1 (50 ng/ml). Cell lysates were analyzed for CCR2A and CCR2B activation by western blot analysis of CCR2A, CCR2B, and $\beta$-actin using specific antibodies. The levels of CCR2A and CCR2B were normalized to those of the corresponding $\beta$-actin protein in the same sample. $\beta$-actin was used as an internal control for even loading. A representative example of three separate experiments is shown. 

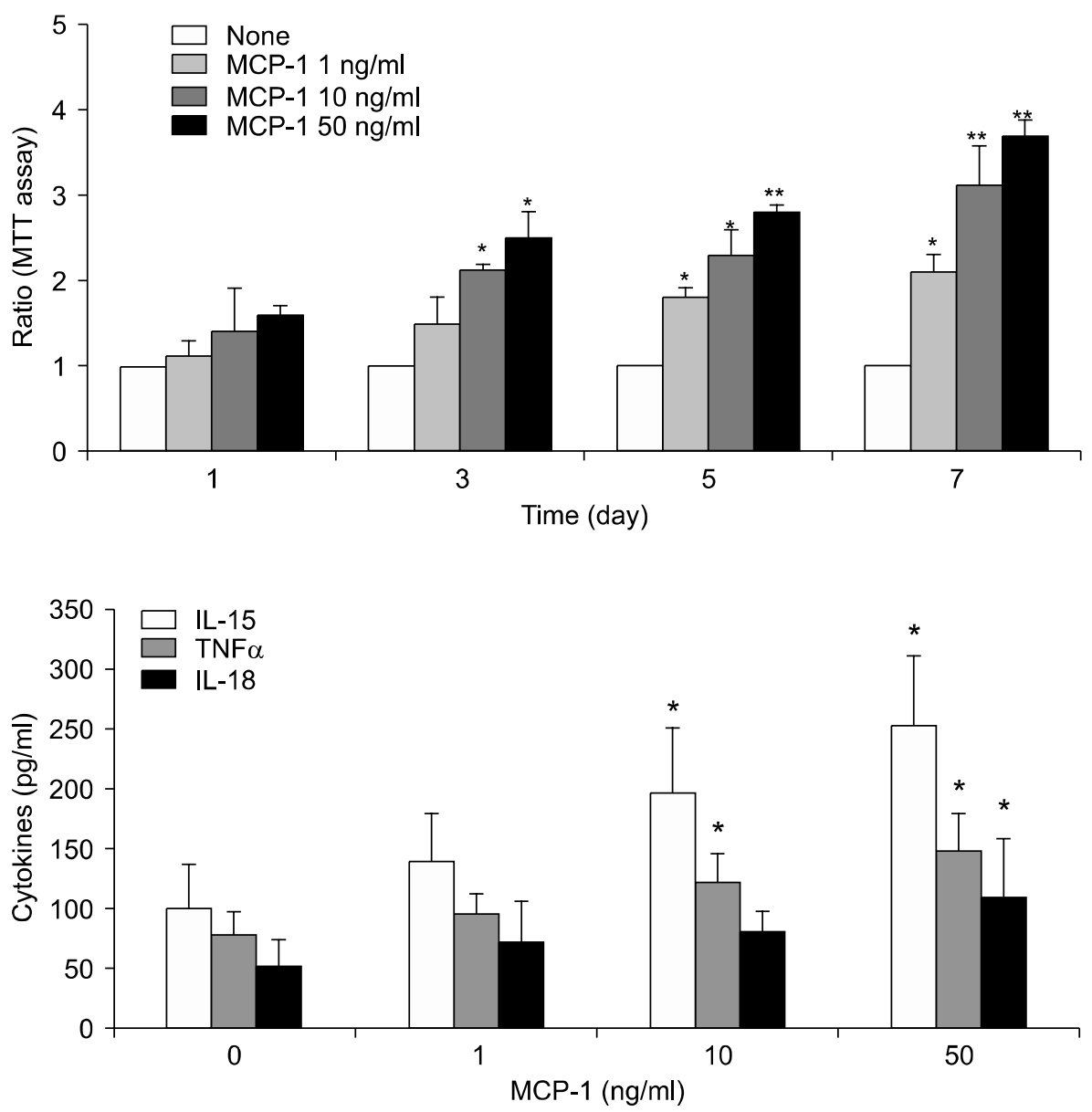

Figure 5. MCP-1 induces proliferation in RA FLS. FLS were cultured with the indicated concentrations of MCP-1 (1-50 $\mathrm{ng} / \mathrm{ml}$ ) from days 1-7. Cellular proliferation was determined by MTT assay. The data are representative of three similar experiments. ${ }^{*} P<0.05,{ }^{* *} P<$ 0.01 . inflammatory cytokine such as IL-15, TNF- $\alpha$, and IL-18 (Figure 6).

\section{Discussion}

We studied the expression of CCR2A and its activation by MCP-1, cytokines, and CD40L in RA FLS. After the two isoforms of CCR2, CCR2A and CCR2B, were first identified, their involvement in idiopathic inflammatory myositis was confirmed by immunohistochemical location (Charo et al., 1994; Sanders et al., 2000; Bartoli et al., 2001). Our study is the first to confirm the presence of CCR2A and CCR2B and to describe the expression of active CCR2A induced by proinflammatory cytokines and CD40L in RA FLS. Immunohistochemistry staining showed CCR2A expression in RA synovium. MCP-1 induced cell proliferation and secretion of the cytokines IL-15, TNF- $\alpha$, and IL-18 in RA FLS. MCP-1 increased the expression of CCR2, especially CCR2A, by increasing the MCP1 concentration in FLS. The effect of MCP-1 on cellular proliferation and cytokine production by FLS was dependent on CCR2A expression. Cytokines such as TGF- $\beta, \mathrm{IL}-1 \beta$, and IL-15 induced a large increase in CCR2A expression.

We propose that CCR2 affects the immune networks and may be regulated by multiple components of the immune systems. Until now, many investigators have studied the roles of CCR2 and MCP-1, and chemokines and chemokine receptors are known to regulate monocyte chemotaxis. CCR2 and MCP-1 have other actions, which may be important in the pathogenesis in RA. MCP-1 enhances the production of MMP-9, a protease involved in tissue damage (Robinson et al., 2002), which regulates the balance between proinflammatory Th1 cells and anti-inflammatory type 2 cytokines (Gu et al., 2000; Sato et al., 2000). MCP-1 can also act as a direct mediator of angiogenesis by increasing CCR2 expression in the endothelium (Salcedo et al., 2000). Chemokine receptors expressed in FLS and RA synoviocytes are thought to be activated by chemokines, and these FLS activated by chemokines may produce 
cytokines and chemokines in an autocrine or paracrine manner (Nanki et al., 2001). One study also found that CCR2 regulates the level of MCP-1 in vitro and at inflammatory sites (Tylaska et al., 2002)

Our data suggest that CCR2A is a possible regulator of chemokines and cytokine production by modulating the level of MCP-1, proliferation, and other actions of CCR2. Therefore, CCR2A, one isoform of CCR2, may be a more specific therapeutic target for suppressing proinflammatory cytokines and depressing FLS proliferation. Treatment with INCB3344, a molecular antagonist of the mouse CCR2 receptor, causes dose-dependent inhibition of macrophage influx and reduction in tissue inflammation (Brodmerkel et al., 2005). INCB3344 administered in vivo inhibits macrophage influx and is efficacious in the mouse EAE and the rat adjuvant arthritis models.

Despite the promises of CCR2A blocking, some problems must be addressed before it can be used for therapeutic applications. Against expectations, CCR2-null mice immunized with type II bovine collagen are more susceptible to collagen-induced arthritis and to an accelerated and more severe disease than are wild-type mice (Quinones et al., 2004).

In another study, CCR2 blockade from days 21 to 36 markedly aggravated clinical and histological signs of arthritis and increased the humoral immune response against collagen (Brühl et al., 2004).

The investigators explained the aggravation of arthritis and humoral immune response as the failure of CCR2+ regulatory $\mathrm{T}$ cell recruitment and their action. CCR2 has dual roles and has both proinflammatory and anti-inflammatory actions. The proinflammatory role of CCR2 is dependent on APCs and T cells, and the anti-inflammatory role of CCR2 is dependent on CCR2 expression in regulatory $\mathrm{T}$ cells. Additional research is required before undertaking therapeutic manipulation of distinct members of the chemokine system such as CCR2.

Expression of CCR2A and CCR2B causes functional differences (Sanders et al., 2000).

MCP-1 stimulates chemotaxis of a CCR2A transfectant without inducing $\mathrm{Ca}^{2+}$ mobilization, but $\mathrm{Ca}^{2+}$ flux is induced in the CCR2B transfectant. In the synoviocyte, CCR2A and CCR2B may have different signaling pathways and different actions. SCD40L also increases the expression of CCR2A. Until now, no study has reported that CD40 ligation affects chemokine receptor expression in FLS. Our data suggest that CD40 ligation may be an alternative pathway for regulating CCR2A expression in RA FLS.
Our results suggest that CCR2A and CCR2B are regulated differently by chemokines, proinflammatory cytokines, and CL40 ligation in RA FLS. In FLS, CCR2A may be an important modulator of the proliferation and production of proinflammatory cytokines. CD40 ligation also seems to be involved in mediating the expression of CCR2A in FLS. Our data suggest the possibility of using selective blocking of CCR2A as a therapeutic target to downregulate FLS proliferation and decrease production of proinflammatory cytokines and chemokines in FLS.

\section{Acknowledgement}

This work was supported by the SRC/ERC program of MOST/KOSEF (grant No. R11-2002-098-05001-0).

\section{References}

Abdi R, Tran TB, Sahagun-Ruiz A, Murphy PM, Brenner BM, Milford EL, McDermott DH. Chemokine receptor polymorphism and risk of acute rejection in human renal transplantation. J Am Soc Nephrol 2002;13:754-8

Bartoli C, Civatte M, Pellissier JF, Figarella-Branger D. CCR2A and CCR2B, the two isoforms of the monocyte chemoattractant protein-1 receptor are up-regulated and expressed by different cell subsets in idiopathic inflammatory myopathies. Acta Neuropathol (Berl) 2001;102:385-92

Brodmerkel CM, Huber R, Covington M, Diamond S, Hall L, Collins R, Leffet L, Gallagher K, Feldman P, Collier P, Stow M, Gu X, Baribaud F, Shin N, Thomas B, Burn T, Hollis G, Yeleswaram S, Solomon K, Friedman S, Wang A, Xue CB, Newton RC, Scherle P, Vaddi K. Discovery and pharmacological characterization of a novel rodent-active CCR2 antagonist, INCB3344. J Immunol 2005;175:5370-8

Brühl H, Cihak J, Schneider MA, Plachý J, Rupp T, Wenzel I, Shakarami M, Milz S, Ellwart JW, Stangassinger M, Schlöndorff D, Mack M. Dual role of CCR2 during initiation and progression of collagen-induced arthritis: evidence for regulatory activity of CCR2+ T cells. J Immunol 2004;172: 890-8

Charo IF, Myers SJ, Herman A, Franci C, Connolly AJ, Coughlin SR. Molecular cloning and functional expression of two monocyte chemoattractant protein 1 receptors reveals alternative splicing of the carboxyl-terminal tails. Proc Natl Acad Sci USA 1994;91:2752-6

Fife BT, Huffnagle GB, Kuziel WA, Karpus WJ. CC chemokine receptor 2 is critical for induction of experimental autoimmune encephalomyelitis. J Exp Med 2000;192: 899-905

García-Vicuña R, Gómez-Gaviro MV, Domínguez-Luis MJ, Pec MK, González-Alvaro I, Alvaro-Gracia JM, DíazGonzález F. CC and CXC chemokine receptors mediate migration, proliferation, and matrix metalloproteinase production by fibroblast-like synoviocytes from rheumatoid arthritis patients. Arthritis Rheum 2004;50:3866-77 
Gu L, Tseng S, Horner RM, Tam C, Loda M, and Rollins BJ. Control of Th2 polarization by the chemokine monocyte chemoattractant protein-1. Nature 2000;404:407-11

Hancock WW, Gao W, Faia KL, Csizmadia V. Chemokines and their receptors in allograft rejection. Curr Opin Immunol 2000;12:511-6

Huang DR, Wang J, Kivisakk P, Rollins BJ, Ransohoff RM. Absence of monocyte chemoattractant protein 1 in mice leads to decreased local macrophage recruitment and antigen-specific $T$ helper cell type 1 immune response in experimental autoimmune encephalomyelitis. J Exp Med 2001;193:713-26

Katschke KJ Jr, Rottman JB, Ruth JH, Qin S, Wu L, LaRosa G, Ponath P, Park CC, Pope RM, Koch AE. Differential expression of chemokine receptors on peripheral blood, synovial fluid, and synovial tissue monocytes/macrophages in rheumatoid arthritis. Arthritis Rheum 2001;44:1022-32

Koch AE, Kunkel SL, Harlow LA, Johnson B, Evanoff HL, Haines GK, Burdick MD, Pope RM, Strieter RM. Enhanced production of monocyte chemoattractant protein-1 in rheumatoid arthritis. J Clin Invest 1992;90:772-9

Koch AE. Review: angiogenesis: implications for rheumatoid arthritis. Arthritis Rheum 1998;41:951-62

Loetscher P, Dewald B, Baggiolini M, Seitz M. Monocyte chemoattractant protein 1 and interleukin 8 production by rheumatoid synoviocytes. Effects of anti-rheumatic drugs. Cytokine 1994;6:162-70

Mack M, Brühl H, Gruber R, Jaeger C, Cihak J, Eiter V, Plachý J, Stangassinger M, Uhlig K, Schattenkirchner M, Schlöndorff $\mathrm{D}$. Predominance of mononuclear cells expressing the chemokine receptor CCR5 in synovial effusions of patients with different forms of arthritis. Arthritis Rheum 1999;42: 981-8

Moore BB, Paine R 3rd, Christensen PJ, Moore TA, Sitterding S, Ngan R, Wilke CA, Kuziel WA, Toews GB. Protection from pulmonary fibrosis in the absence of CCR2 signaling. $J$ Immunol 2001;167:4368-77

Nanki T, Nagasaka K, Hayashida K, Saita Y, Miyasaka N. Chemokines regulate IL-6 and IL-8 production by fibroblast-like synoviocytes from patients with rheumatoid arthritis. J Immunol 2001;167:5381-5

Nawrot U, Grzybek-Hryncewicz K, Zielska U, Czarny A, Podwinska J. The study of cell-mediated immune response in recurrent vulvovaginal candidiasis. FEMS Immunol Med Microbiol 2000;29:89-94

Paine R 3rd, Rolfe MW, Standiford TJ, Burdick MD, Rollins BJ, Strieter RM. MCP-1 expression by rat type II alveolar epithelial cells in primary culture. J Immunol 1993;150: 4561-70

Polentarutti N, Allavena P, Bianchi G, Giardina G, Basile A, Sozzani S, Mantovani A, Introna M. IL-2-regulated expression of the monocyte chemotactic protein-1 receptor (CCR2) in human NK cells: characterization of a predominant 3.4-kilobase transcript containing CCR2B and CCR2A sequences. J Immunol 1997;158:2689-94

Quinones MP, Ahuja SK, Jimenez F, Schaefer J, Garavito E,
Rao A, Chenaux G, Reddick RL, Kuziel WA, Ahuja SS. Experimental arthritis in CC chemokine receptor 2-null mice closely mimics severe human rheumatoid arthritis. J Clin Invest 2004;113:856-66

Quinones MP, Estrada CA, Kalkonde Y, Ahuja SK, Kuziel WA, Mack M, Ahuja SS. The complex role of the chemokine receptor CCR2 in collagen-induced arthritis: implications for therapeutic targeting of CCR2 in rheumatoid arthritis. J Mol Med 2005;83:672-81

Robinson SC, Scott KA, Balkwill FR. Chemokine stimulation of monocyte matrix metalloproteinase-9 requires endogenous TNF-alpha. Eur J Immunol 2002;32:404-12

Ruth JH, Rottman JB, Katschke KJ Jr, Qin S, Wu L, LaRosa G, Ponath P, Pope RM, Koch AE. Selective lymphocyte chemokine receptor expression in the rheumatoid joint. Arthritis Rheum 2001;44:2750-60

Salcedo R, Ponce ML, Young HA, Wasserman K, Ward JM, Kleinman HK, Oppenheim JJ, Murphy WJ. Human endothelial cells express CCR2 and respond to MCP-1: direct role of MCP-1 in angiogenesis and tumor progression. Blood 2000;96:34-40

Sanders SK, Crean SM, Boxer PA, Kellner D, LaRosa GJ, Hunt SW 3rd. Functional differences between monocyte chemotactic protein- 1 receptor $A$ and monocyte chemotactic protein-1 receptor $B$ expressed in a Jurkat T cell. J Immunol 2000;165:4877-83

Sato N, Ahuja SK, Quinones M, Kostecki V, Reddick RL, Melby PC, Kuziel WA, Ahuja SS. CC chemokine receptor (CCR)2 is required for langerhans cell migration and localization of T helper cell type 1 (Th1)-inducing dendritic cells. Absence of CCR2 shifts the Leishmania majorresistant phenotype to a susceptible state dominated by Th2 cytokines, b cell outgrowth, and sustained neutrophilic inflammation. J Exp Med 2000;192:205-18

Segerer S, Cui Y, Hudkins KL, Goodpaster T, Eitner F, Mack $M$, Schlondorff $D$, Alpers $C E$. Expression of the chemokine monocyte chemoattractant protein-1 and its receptor chemokine receptor 2 in human crescentic glomerulonephritis. J Am Soc Nephrol 2000;11:2231-42

Shahrara S, Amin MA, Woods JM, Haines GK, Koch AE. Chemokine receptor expression and in vivo signaling pathways in the joints of rats with adjuvant-induced arthritis. Arthritis Rheum 2003;48:3568-83

Springer TA. Traffic signals for lymphocyte recirculation and leukocyte emigration: the multistep paradigm. Cell 1994;76: 301-14

Tylaska LA, Boring L, Weng W, Aiello R, Charo IF, Rollins BJ, Gladue RP. CCR2 regulates the level of MCP-1/CCL2 in vitro and at inflammatory sites and controls $\mathrm{T}$ cell activation in response to alloantigen. Cytokine 2002;18:184-90

Wang JM, Sica A, Peri G, Walter S, Padura IM, Libby P, Ceska M, Lindley I, Colotta F, Mantovani A. Expression of monocyte chemotactic protein and interleukin- 8 by cytokine-activated human vascular smooth muscle cells. Arterioscler Thromb 1991;11:1166-74

Weyand CM. New insights into the pathogenesis of rheumatoid arthritis. Rheumatology (Oxford) 2000;39 Suppl 1:3-8 